\title{
Havza Bazlı Bitkisel Üretim ve Sulama Suyu Optimizasyon Çalıșmaları ve Önemi
}

\author{
Gonca KARACA BILGEN'** (ID) Süleyman KODAL² (ID) Yusuf Ersoy YILDIRIM² (ID
}

'Tarımsal Araștırmalar ve Politikalar Genel Müdürlüğü, Ankara

${ }^{2}$ Ankara Üniversitesi Ziraat Fakültesi Tarımsal Yapılar ve Sulama Bölümü, Ankara

\author{
*Sorumlu yazar eposta: gonca.karacabilgen@tarimorman.gov.tr \\ Geliș tarihi (Received): 09.07.2019 \\ Kabul tarihi (Accepted): 19.07.2019 \\ DOI: 10.21657/topraksu.655499
}

\section{Öz}

Etkin bir sulamanın önündeki sorunların tespit edilmesinin yanı sıra Türkiye'de tarımın yoğun olarak yapıldığı havzalarda çiftçi gelirinin maksimizasyonu için, o ișletmede hangi ürünün yetiștirilmesi gerektiği, o ürünün hangi ekiliș oranında yetiștirileceği ve ne kadar sulama suyu uygulanacağı belirlenerek o havzada yetiștirilmesi gereken bitkilerin optimizasyonu yapılmalıdır. Söz konusu bu çalıșmada bitki deseni optimizasyonu çalıșmaları yapılırken temel veri olarak bitki su tüketimleri ve bitkilerin üretim maliyet ve net gelirleri kullanıımıștır. Bitkilerin su tüketimleri Penman Monteith yöntemiyle hesaplanmıștır. Bitkilerin su tüketimleri 10'ar günlük dönemler için hesaplanmıș ve toplamları alınarak aylık ve mevsimlik su tüketimleri elde edilmiștir. Bitkilerin tam sulama (\%100 su) ve kısıntılı sulamalar (\%80, \%60 ve \%40 su) için sulama zaman planlarının (sulama programlarının) elde edilmesinde IRSIS yazılımı kullanılmıștır. Her bitki için sulama suyu miktarları ve verim değerlerinden yararlanılarak sulama suyu-verim ilișkisi elde edilmiștir. Daha sonra doğrusal olmayan programlama tekniği ile her havza için farklı su kaynağı kapasitelerinde maksimum ișletme gelirini sağlayacak optimum bitki deseni belirlenmiștir. Sonuç olarak çalıșmaların yürütüldüğü havzalarda 100 da büyüklüğündeki bir tarım ișletmesi için toplam sulama suyu intiyacı ve net gelir değerleri elde edilmiștir. Sulama politikaları ve sulama etkinliği konusunda çalıșan kamu-kurum ve özel sektör uzmanlarının ve karar vericilerin sulama yatıımı ve ișletilmesi konularında politika geliștirmede kullanabileceği bilgiler elde edilmiștir.

Anahtar kelimeler : Optimum bitki deseni sulama etkinliği, sulama politikaları

\section{Watershed-Based Crop Production and Irrigation Water Optimization Studies and Importance}

\begin{abstract}
In addition to detecting problems with an effective irrigation, for the maximization of farmer income in the basins where agriculture is concentrated in Turkey, it is necessary to optimize the crops in that basin by determining the crops that should be grown, the area at which the crops will be grown and how much irrigation water will be applied. In this study plant water consumption and production costs and net income of plants were used as basic data in crop pattern optimization studies. The water consumption of plants is calculated by Penman Monteith method. The water consumption of the plants was calculated for 10-day periods and the monthly and seasonal water consumption was obtained by taking the totals. IRSIS software was used to obtain irrigation programs for full irrigation (100\% water) and deficit irrigations (80\%, 60\% and 40\% water). Irrigation water-yield relationship was obtained by
\end{abstract}


using irrigation water quantities and yield values for each plant. The non-linear programming technique was then used to determine the optimal crop pattern for each basin to provide maximum operating revenue for different water resource capacities. As a result, total irrigation water needs and net income values were obtained for a farm in the size of 10 ha in the basins where the studies were carried out. Information on the use of irrigation policies and irrigation efficiency by public-private and private sector experts and decision-makers on irrigation investment and management issues has been obtained.

Keywords: Irrigation efficiency, irrigation policy, optimum crop pattern

\section{Gíriș}

Özellikle küresel iklim değișikliğinin su kaynakları üzerinde yaratacağı etkilerin belirsizliği su yönetimdeki belirsizlikleri artırmıștır. Sulama suyunun kısıtlı ve pahalı olduğu yerlerde su tasarrufu sağlayabilecek yeni yöntemlerin seçimi yanında kısıntıı sulama uygulaması da bir alternatif olarak göz önünde tutulmaktadır. Kısıntılı sulama, belirli seviyelerde su eksikliğine ve bitki verimi azalmasına izin verilmesi durumunda yapılan bir yaklașımdır. Sulu tarım ișletmesinde gerek yeterli gerekse kısıtlı su koșullarında su kullanım etkinliğini arttıran ve aynı su ile daha fazla gelir elde edilmesini sağlayan tedbirlerden biri de ișletme için optimum bitki deseninin belirlenmesidir. Optimum bitki deseni çalıșmalarının hedefi ișletme gelirini maksimize etmek ve kısıtlı su kaynakklarını etkin kullanmaktır.

Havza bazlı su yönetiminin olușturulmasında su havzaları ve tarım havzaları örtüștürülmeli ve geleceğe yönelik havza bazlı çalıșmalarda tarım havzaları da göz önünde bulundurulmalı, her havza kendi șartlarına göre planlanmalıdır.

Bu çalıșmada tarımın yoğun olarak yapıldığı havzalarda çiftçi gelirinin maksimizasyonu için o ișletmede hangi ürünün yetiștirilmesi gerektiği, o ürünün kaç dekar alanda (veya hangi ekiliș oranında) yetiștirileceği ve ne kadar sulama suyu uygulanacağına ilișkin çalıșmalar yapıımıı̦tır (Kodal vd., 2016).

\section{MATERYAL VE YÖNTEM}

Türkiye 25 hidrolojik havzaya bölünmüș olup bu çalıșmada 22 havza değerlendirilmiștir. Hesaplamalarda değerlendirilen istasyon illeri ve maliyetlerine ulașılan bitki sayıları Çizelge l'de verilmiștir.

Havzaların seçiminde sulamaya intiyaç duyulma durumu ve yeterli bitki maliyet verisi elde edilme durumu dikkate alınmıștır. Doğu Karadeniz, Batı Karadeniz, Asi, Coruh ve Van havzaları değerlendirmeye alınmamıștır. Bitkilerin su tüketimleri Penman Monteith yöntemiyle onar günlük dönemler için hesaplanmıștır (Güngör vd., 2004). Bitki su tüketimleri TAGEM ve bağlı araștırma enstitüleri, DSi ve bazı üniversitelerin katılımı ile gerçekleștirilen Türkiye'de Sulanan Bitkilerin Bitki Su Tüketimleri isimli rehberden alınarak hesaplanmıștır (Anonim, 2017).

Çizelge 1. Havza bazlı hesaplamalarda ele alınan il ve bitki sayıları

Table 1. Number of provinces and plants discussed in basinbased calculations

\begin{tabular}{cccc}
\hline Sıra no & Havza & İstasyon-II & Bitki sayısı \\
\hline 1 & Akarçay & Afyon & 3 \\
2 & Antalya & Antalya & 4 \\
3 & Aras & Iğdır & 4 \\
4 & Așağı Fırat & Șanlıurfa & 5 \\
5 & Batı Akdeniz & Fethiye-Muğla & 5 \\
6 & Büyük Menderes & Aydın & 3 \\
7 & Burdur & Burdur & 5 \\
8 & Ceyhan & Adana & 26 \\
9 & Dicle & Diyarbakır & 4 \\
10 & Doğu Akdeniz & Tarsus-Mersin & 25 \\
11 & Gediz & Manisa & 12 \\
12 & Küçük Menderes & Ödemiș-lzmir & 14 \\
13 & Kızılırmak & Bafra-Samsun & 13 \\
14 & Konya & Konya & 9 \\
15 & Kuzey Ege & Bergama-İzmir & 15 \\
16 & Marmara & Bursa & 13 \\
17 & Meriç-Ergene & Edirne & 4 \\
18 & Sakarya & Eskișehir & 3 \\
19 & Seyhan & Adana & 26 \\
20 & Susurluk & Balıkesir & 9 \\
21 & Yeșilımak & Tokat & 10 \\
22 & Yukarı Fırat & Elazığ & 4 \\
\hline & Toplam & & 216 \\
\hline
\end{tabular}

Bitkilerin tam sulama (\%100 su) ve kısıntılı sulamalar (\%80, \%60 ve \%40 su) için sulama zaman planlarının (sulama programlarının) elde edilmesinde IRSIS yazılımı kullanılmıștır. Çözümler her iklim istasyonu ve her bitkinin 4 farklı su düzeyi için ayrı ayrı yapılmıștır. Her sulama zaman 
planı ile mevcut koșullarda kaç sulama yapılması, ne kadar sulama suyu verilmesi gerektiği ve alınabilecek verim oranı elde edilmiștir (Kodal, 2011). Her bitki için sulama suyu miktarları ve verim değerlerinden yararlanılarak sulama suyuverim ilișkisi elde edilmiștir. Bu sonuçlar bitkilerin net gelir değerlerinin ve su-gelir ilișkilerinin hesaplanmasında kullanılmıștır.

\section{BULGULAR VE TARTIȘMA}

Bu çalıșmada 2015 yılı için net gelir değerleri kullanılmıștır. Yeterli verinin elde edilebilmesi durumunda son 5 veya son 10 yıla ilișkin net gelir tablolarının ortalama değerlerinin kullanılmasında yarar bulunmaktadır. Ayrıca maliyeti bulunabilen bitki sayısı az, su tüketimi bulunabilen bitki sayısı daha fazla olmuș, ancak maliyet bilgisi olan bazı bitkilerde su tüketimi bulunamamıștır, bu nedenle değerlendirmeye alınan bitki sayısı bazı havzalarda 3'e kadar düșmüștür.

Alınan maliyet çizelgeleri tam sulama için net gelir değerlerine karșllık gelmektedir. Bu çizelgelerde, kısıntılı sulamalar için IRSIS yazılımı ile belirlenen sulama zaman planlaması sonuçlarından yararlanılarak, verime göre değișen üretim masrafları ve sulama masrafları yeniden hesaplanmıș ve kısıntılı sulama zaman planları için net gelir değerleri hesaplanmıștır (Kodal, 2011). Her bitki için net sulama suyu ve gelir değerlerinden yararlanılarak bitki sulama suyugelir ilișkisi elde edilmiștir.

Çalıșmaların yapııdığı her havza sulama alanları için optimum bitki deseninin ve sulama suyu-net gelir ilișkisinin belirlenmesinde doğrusal olmayan programlama tekniğinden yararlanılmıștır. Çözümlemeler Excel yazılımı ile yapılmıștır. Olușturulan modelin amaç fonksiyonunda bitkilerin su-gelir ilișkileri yer almıștır. Modelin kısıtlar bölümünde ise ekim alanı, ikinci ürün ekim alanı, nadas, bitkilerin maksimum ve minimum ekim oranları, sulama suyu miktarı gibi kısıtlar yer almıștır. Modelin çözümü ile 100 da büyüklüğünde bir ișletmede en yüksek bitkisel üretim gelirinin elde edilebilmesi için hangi bitkinin, kaç dekar alanda, ne kadar sulama suyu verilerek yetiștirilmesi gerektiği, bu durumda toplam bitkisel üretim gelirinin ne kadar olacağı belirlenmiștir (Kodal, 2011).

Çizelge 2. Adana ilinde bitkilere göre mevsimlik su tüketimleri

Table 2. Seasonal evapotranspiration to plants in Adana province

\begin{tabular}{|c|c|c|c|c|c|c|c|c|c|}
\hline Bitki & $\begin{array}{l}\text { Ekim } \\
\text { Tarihi }\end{array}$ & $\begin{array}{l}\text { Hasat } \\
\text { Tarihi }\end{array}$ & $\begin{array}{l}\text { Yetișme } \\
\text { Dönemi } \\
\text { Uzunluğu } \\
\text { (gün) }\end{array}$ & $\begin{array}{c}\text { Mevsimlik } \\
\text { Bitki Su } \\
\text { Tüketimi, } \\
\text { ETm (mm) }\end{array}$ & Bitki & $\begin{array}{l}\text { Ekim } \\
\text { Tarihi }\end{array}$ & $\begin{array}{l}\text { Hasat } \\
\text { Tarihi }\end{array}$ & $\begin{array}{c}\text { Yetișme } \\
\text { Dönemi } \\
\text { Uzunluğu } \\
\text { (gün) }\end{array}$ & $\begin{array}{c}\text { Mevsimlik } \\
\text { Bitki Su } \\
\text { Tüketimi, } \\
\text { ETm (mm) }\end{array}$ \\
\hline Ayçiçeği & 15.3 & 27.7 & 134 & 504 & Mısır(dane) 2. ürün & 20.6 & 17.10 & 119 & 432 \\
\hline Ayçiçeği (2. ürün) & 25.6 & 27.9 & 94 & 324 & Mısır (silaj) 2. ürün) & 20.6 & 17.9 & 89 & 327 \\
\hline Bakla (taze) & 15.10 & 13.3 & 149 & 199 & Narenciye & 1.1 & 31.12 & 364 & 819 \\
\hline Balkabağı & 15.4 & 21.9 & 159 & 641 & Pamuk & 15.4 & 11.10 & 179 & 742 \\
\hline Bamya & 15.4 & 27.8 & 134 & 610 & Patates & 15.4 & 12.8 & 119 & 529 \\
\hline Biber (salça) & 1.4 & 22.9 & 174 & 744 & Patates (turfanda) & 1.11 & 19.4 & 169 & 288 \\
\hline Buğday (kıșlık) & 15.11 & 2.6 & 199 & 427 & Patlıcan & 1.4 & 28.8 & 149 & 623 \\
\hline Çeltik & 20.4 & 6.10 & 169 & 717 & Soğan (yeșil) & 1.4 & 9.6 & 69 & 199 \\
\hline Çeltik (2. Ürün) & 15.6 & 17.10 & 124 & 457 & Sorgum (silajlık) & 1.5 & 28.8 & 119 & 478 \\
\hline Çilek & 15.2 & 12.10 & 239 & 818 & Soya fasulyesi & 25.4 & 11.9 & 139 & 578 \\
\hline Domates (yer) & 1.4 & 8.8 & 129 & 563 & Soya fasulyesi (2. ürün) & 8.10 & 25.4 & 199 & 273 \\
\hline Elma & 25.3 & 9.11 & 229 & 853 & Susam & 25.4 & 22.8 & 119 & 509 \\
\hline Erik & 15.3 & 9.11 & 239 & 863 & Susam (2. ürün) & 20.6 & 7.10 & 109 & 361 \\
\hline Fasulye (taze) & 10.3 & 12.7 & 124 & 491 & Șeftali & 20.2 & 17.10 & 239 & 905 \\
\hline Hiyar & 20.3 & 17.7 & 119 & 438 & Üzüm (sofralık, kuru) & 1.3 & 11.10 & 224 & 768 \\
\hline Hıyar (2. ürün) & 10.7 & 22.10 & 104 & 277 & Üzüm (șaraplık) & 1.3 & 11.10 & 224 & 619 \\
\hline Karpuz & 15.3 & 22.6 & 99 & 334 & Yerfıstığı & 1.5 & 27.10 & 179 & 652 \\
\hline Kiraz & 15.3 & 9.11 & 239 & 852 & Yerfıstığı (2. ürün) & 20.6 & 17.10 & 119 & 383 \\
\hline Maydanoz & 1.1 & 3.3 & 61 & 793 & Yonca & 10.2 & 8.4 & 57 & 980 \\
\hline Mısır (dane) & 15.3 & 11.8 & 149 & 664 & Zeytin (yağlık) & 5.3 & 30.10 & 239 & 647 \\
\hline
\end{tabular}


Optimum bitki deseni çözümleri sonucunda belirlenen ișletme için gerekli net sulama suyu intiyaçları sulama randımanına bölünerek brüt (toplam) sulama suyu intiyacına çevrilmiștir. Havzalar arasında karșılaștırma yapılabilmesi için tüm havzalarda sulama randımanı 0,60 olarak alınmıștır. Optimum bitki desenleri belirlendikten sonra her havza için toplam sulama suyu-net gelir eșitlikleri elde edilmiștir.

Așağıdaki bölümde Seyhan Havzası için optimum bitki deseni çalıșmaları ayrıntılı olarak açıklanmıș ve tüm havzaların optimum bitki desenleri, su-gelir eșitlikleri ve sonuçların karșılaștırılması verilmiștir.

\section{Seyhan Havzası optimum bitki deseni}

Çalıșmada Seyhan havzasında bulunan Adana ili, tarımsal arazisi ve sulama alanlarının çok olması bakımından örnek olarak seçilmiș ve optimum ürün deseni çıkarılmıștır. Adana ilinde yetiștirilen bitkilerin su tüketimleri Çizelge 2'de verilmiștir. Çizelgede bitkilerin hesaplamalarda kullanılan ekim ve hasat tarihleri ve yetișme dönemi uzunlukları da görülmektedir.

\section{Sulama zaman planlaması}

Her havzada her bitki için tam sulama (\%100 su) ve kısıntılı sulamalar (\%80, \%60 ve \%40 su) için sulama zaman planları (sulama programları) elde edilmiș ve bitkiye verilmesi gereken sulama suyu miktarı, sulama sayısı, verim düzeyi gibi sonuçlar belirlenmiștir. Bu planlama sonuçlarından yararlanılarak her istasyon ve her bitki için sulama suyu miktarı ile verim arasındaki ilișkiler elde edilmiș olup örnek olarak karpuz için su-verim ilișkisi Șekil 1 ' de verilmiștir.

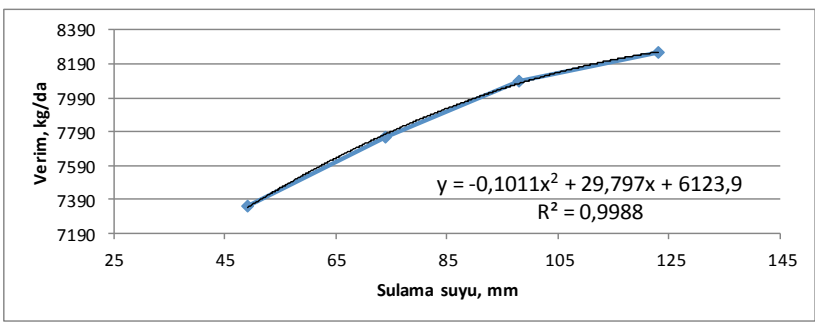

Șekil 1. Karpuz için sulama suyu-verim ilișkisi

Figure 1. Irrigation water-yield relationship of watermelon

\section{Bitkilerin net gelir değerleri ve su-gelir ilișkileri}

Farklı sulama suyu miktarı (net su) ve karșilık gelen gelir değerlerinden yararlanılarak her havzada her bitki için sulama suyu-gelir ilișkisi elde edilmiștir. Örnek olarak karpuz için su-gelir ilișkisi Șekil Z'de verilmiștir.

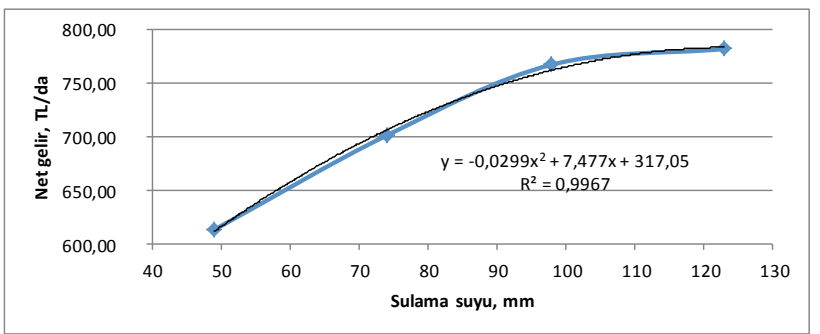

Șekil 2. Karpuz için sulama suyu-gelir ilișkisi

Figure 2. IIrrigation water-income relationship for watermelon

\section{Optimum bitki deseni ve bitkisel üretim geliri}

Farklı su kapasitesine sahip ișletmeler için belirlenen optimum bitki deseni, optimum sulama suyu miktarı ve ișletme geliri Çizelge 3'de verilmiștir.

Yeterli suya sahip ișletmede (K100) buğday, çilek, domates, erik, hıyar, patlıcan, patates ve yerfıstığı-2 bitkileri yer almıștır. Sulu ana ürün bitkilerin ekim alanı toplamı 100 da dır. 20 da buğdaydan sonra ikinci ürün ekimi vardır (yerfıstığı-2). Bu ișletmede bitki deseninde yer alan tüm bitkilere verilmesi gereken sulama suyu miktarı maksimumdur (\%100), yani tam sulama yapılmalıdır, kısıntıı sulama yapılmamalıdır. Bu ișletmenin net geliri 169,762 TL, verilmesi gereken sulama suyu ise brüt $67.667 \mathrm{~m}^{3}$ tür. Birim alan geliri 1,679 TL da', birim su geliri 2.51 TL m $\mathrm{Tu}^{-3}$.

İșletmenin su kapasitesi azaldıkça ya bitkilerin alanı azalmakta, ya bitkiye verilecek su miktarı azalmakta ya da o bitki desenden çıkmakta ve bașka bir bitki desene girmekte, ișletme geliri azalmaktadır. Çizelgede dikkat çeken nokta, ișletme su kapasitesinin \%10 azalmasına karșın (K90), ișletme gelirinin çok az azaldığıdır. K90 ișletmesinin geliri \%1 azalmıștır. K50 ișletmesinde su kapasitesi \%50 azaldığı halde geliri \%33 azalmıștır. Bu sonuçlar optimum bitki deseni çalıșmalarının önemini göstermektedir.

Sulama suyu kapasitesinin \%20 olduğu (8.120 $\mathrm{m}^{3}$ suya sahip) ișletmede bitki deseninde 10 da domates olmalı ve tam sulama yapılmall, 10 da hıyar olmalı ve tam sulama yapılmalı, 2.47 da patlıcan olmalı ve tam sulama yapilmalı, 7.53 da soğan olmalı ve yine tam sulama yapılmalıdır. Bu durumda maksimum ișletme geliri elde edilebilecektir. 30 da alanda sulu tarım yapılacak ve kalan 70 da alan boș bırakılacak veya kuru tarım yapılacaktır (kuru tarım 
Çizelge 3. Seyhan havzasında 100 da ișletme için optimum bitki deseni sonuçları

Table 3. Optimum plant pattern results for 100 da in Seyhan Basin

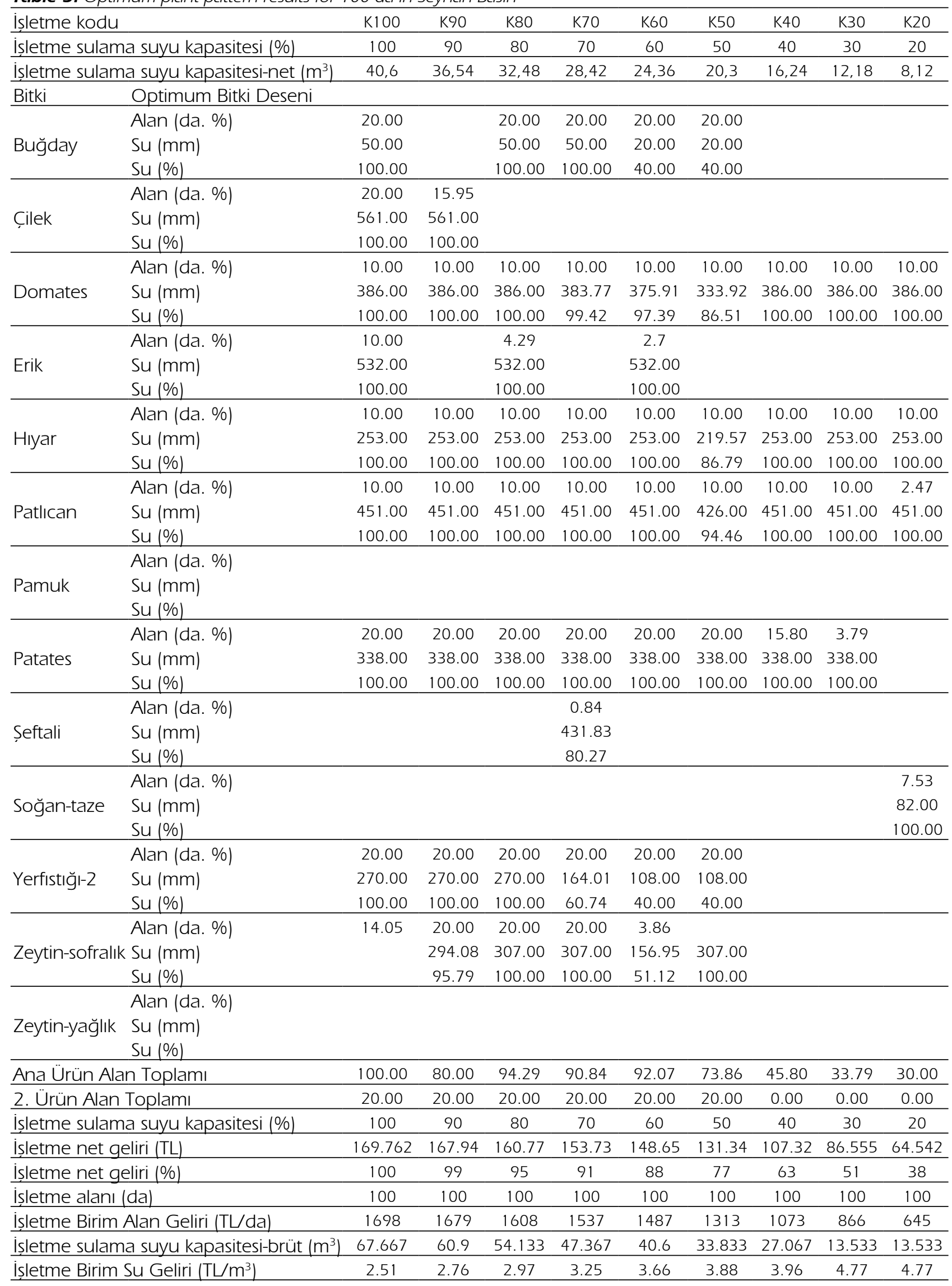


yapılması durumunda ișletme geliri az miktarda artacaktır ancak bu çalıșmada kuru bitkilerin üretimi dikkate alınmamıștır). Sulu bitkilerden elde edilecek gelirin 64,542 TL olması beklenmektedir. Bu ișletmenin birim alan geliri $645 \mathrm{TL} \mathrm{da}^{-1} \mathrm{dır}$.

İșletmenin birim su geliri yeterli su kapasitesinde 2,.51 TL m³ iken su kapasitesi azaldıkça bu değer artmakta ve \%20 kapasiteye sahip ișletmede 4,77 $\mathrm{TL} \mathrm{m}^{-3}$ e yükselmektedir.

Elde edilen optimum bitki deseni sonuçlarının uygulamada elde edilebilmesi için bu çalıșmada yapıldığı gibi bitki su tüketimlerinin, sulama zaman planlamasının, sulama uygulamasının doğru veyöre koșullarına uygun șekilde yapılması gerekmektedir. Bu çalıșmaları çiftçinin tek bașına yapması elbette beklenemez, ilgili kurumların desteği ve bu konuda çiftçi eğitimi yapılması zorunlu görülmektedir.

Seyhan havzasında yapılan bir çalıșmada optimum bitki deseni çalıșması sonucunda belirlenen çiftçi gelirinin, mevcut durumdaki ișletme gelirin yaklașık 8 katı olduğu, ayrıca çiftçinin optimum bitki deseni çalıșması sonucunda belirlenen suyun yaklașık 2 katını kullandığı belirlenmiștir. Bu sonuç hem așırı sulamanın önlenmesi hem de aynı suyla daha fazla gelir elde edilebilmesi için yapılması gereken çalıșmalar arasında optimum bitki deseni çalıșmalarının önemini açıkça ortaya koymaktadır (Anonim 2016).

\section{Sulama suyu-ișletme bitkisel üretim geliri ilișkisi}

Adana için örnek tarım ișletmesinde ișletme su kapasitesi ile ișletme geliri arasındaki ilișki Șekil 3'de verilmiștir. Verilen eșitlik, bu havzada 100 da büyüklüğündeki bir ișletmede bitkisel üretime ayrılacak sulama suyu miktarının bilinmesi halinde elde edilecek net gelir değerinin hesaplanmasında kullanılabilir.

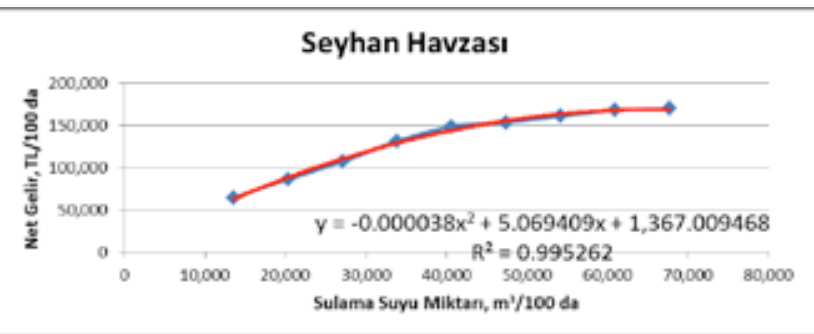

Şekil 3. Seyhan havzasında ișletmenin su kapasitesi ile ișletme geliri arasındaki ilișki

Figure 3. Relationship between water capacity and income of the enterprise in Seyhan Basin

\section{Havzalarda ișletme su kapasitesi ișletme geliri ve birim su geliri sonuçları}

Bu bölümde net gelir değeri bulunabilen bitki sayısının 9 dan fazla olduğu havzalar dikkate alınmıștır. Șekil 4'de su kaynağının yeterli olduğu koșulda havzalarda birim alandan elde edilebilecek net gelir, bu geliri elde etmek için gerekli olan sulama suyu miktarı ve birim suya karșıllk elde edilecek gelir değerleri verilmiștir. Havzalarda ișletme geliri grafiği incelendiğinde K. Menderes ve Kuzey Ege havzalarında gelir değerinin oldukça yüksek olduğu görülmektedir (5.000 TL nin üzerinde) diğer havzalarda ise birbirine yakındır ve $2.000 \mathrm{TL}$ nin altındadır. K. Menderes ve kuzey Ege havzalarında gelir değerinin oldukça yüksek olmasının nedeni, havzalarda yeterli sayıda bitki ile çalıșlamaması ve çalıșmanın yapııdığı yıl bazı bitkilerin net gelir değerlerinin yüksek, bazılarının sıfır hatta negatif olması olabilir. Bu nedenle bitkilerin tek bir yıla ilișkin net gelir değerleri yerine birkaç yıla ilișkin net gelir değerlerinin kullanılmasında yarar görülmektedir.

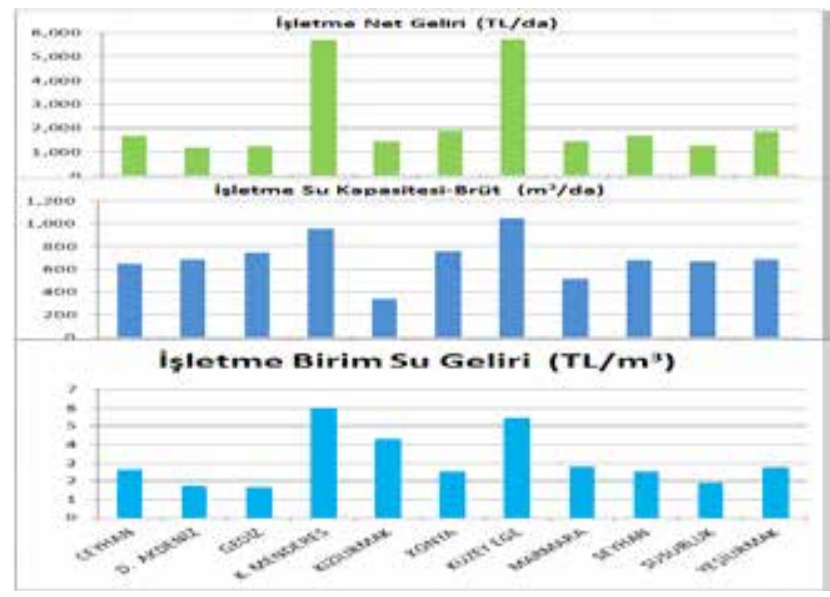

Șekil 4. Havzalarda yeterli su koșulunda net gelir su kapasitesi ve birim alan net gelirlerin dağııımı

Figure 4. Net income water capacity and distribution of net revenues in the basins under adequate water conditions

Havzalarda belirtilen gelirin elde edilebilmesi için gerekli sulama suyu miktarı incelendiğinde yine K. Menderes ve kuzey Ege havzalarında gerekli su miktarının diğer havzalara oranla daha yüksek olduğu görülmektedir, en düșük değer ise Kızılırmak havzasındadır. Havzalarda birim suya karșlık elde edilecek gelir değerleri grafiği incelendiğinde yine K. Menderes ve kuzey Ege havzalarında birim su geliri değerinin diğer havzalara oranla yüksek olduğu görülmektedir.

Gelir değerleri havzanın veya istasyonun bașta yağıș olmak üzere iklim koșullarına, yetiștirilen 
bitkilere ve su tüketimlerine göre değișim göstermektedir. Bu sonuçlarda elbette ki bazı havzalarda yeterli sayıda bitkiye ilișkin bilginin elde edilememesi de etkili olabilir. Doğudaki havzalarda net gelirin daha düșük, batıdaki havzalarda ise yüksek olduğu görülmektedir.

Bu tür değerlendirmeler su kaynağının yeterli olduğu koșul yanında su kaynağının kısıtlı olduğu farklı sulama suyu düzeyleri için de yapılabilir. İncelenen en düșük su kaynağı (\%20) koșulunda havzalarda birim alandan elde edilebilecek net gelir, bu geliri elde etmek için gerekli olan sulama suyu miktarı ve birim suya karșılık elde edilecek gelir değerleri Șekil 5'de verilmiștir. Buna göre \%20 su kapasitesinde birim alandan elde edilebilecek gelir değeri yine K. Menderes ve Kuzey Ege havzalarındadır ve 2000-2500 TL civarındadır. Diğer havzalarda ise 1000 TL nin altındadır. Yeterli su kapasitesi ile karșılaștırılırsa gelir yaklașık yarıya düșmektedir (su kapasitesi \%80 azaldığı halde). Tabii ki bu durum sulamanın tekniğine uygun ve sulama zaman planlaması ile desteklenmesi ve optimum bitki deseni çalıșması yapııması ile mümkün olabilecektir. Birim su geliri ise $\mathrm{K}$. Menderes, Kızılırmak ve Kuzey Ege havzalarında daha yüksektir, ancak bu su düzeyinde birim su geliri tam su düzeyindeki değerin yaklașık 2 katıdır (14 TL civarında).

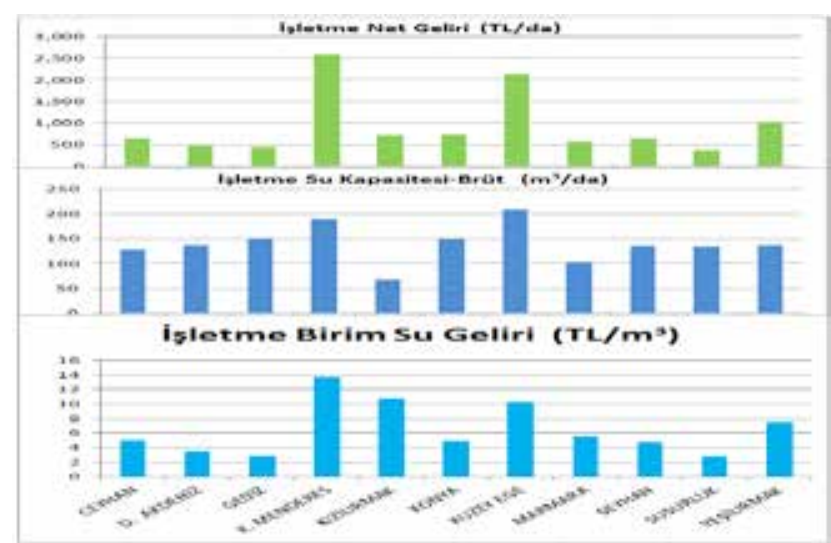

Șekil 5. Havzalarda kısıtlı su (\%20) koșulunda net gelir su kapasitesi ve birim alan net gelirlerin dağılımı

Figure 5. Net income water capacity and distribution of net revenues in the basins with limited water condition (20\%)

\section{SONUC̣LAR}

Tarım alanlarında optimum bitki deseninin belirlenmesi çalıșmaları, çiftçilerin mevcut uygulamalarına oranla daha az su ile daha fazla gelir elde etmeleri açısından önem tașımaktadır.
Nitekim havza bazlı sektörel su tahsisi projeleri șu anda 3 havzada çalıșılmaya bașlanmıștır. Bu çalıșmalarda tarım sektörüne normal ve kurak yıllarda ne kadar sulama suyu ayrıldığında ne kadar gelir elde edilebileceği bitki deseni optimizasyonu ile belirlenmektedir.

Bu tür çalıșmaların havza, alt havza, mikro havza, ova vb. bazında yapılması durumunda elde edilecek sonuçların ülkemizde özellikle su kaynaklarının yetersiz olduğu bölgelerde sulama politikaları, sulama yatıımlarına karar verilmesi, sulama sistemlerinin ișletilmesi, desteklenecek ürünlere karar verilmesi gibi konularda çalıșan yönetici ve teknik elemanlara çok yardımcı olacağı așikardır.

Özellikle su kaynaklarının yetersiz olduğu koșulda toplam alandan en yüksek gelirin elde edilebilmesi için hangi sulama alanına hangi oranda sulama suyu verileceği, verilen suyla hangi bitkilerin yetiștirileceği ve her bitkiye ne oranda sulama suyu verileceği belirlenebilir.

$\mathrm{Bu}$ tür çalıșma sonuçları tarımsal üretim planlaması amacıyla da kullanılabilir. Belirli bitkilerden en yüksek üretim miktarının elde edilebilmesi için hangi sulama alanına hangi oranda sulama suyu verileceği, verilen suyla hangi bitkilerin yetiștirileceği ve her bitkiye ne oranda sulama suyu verileceği belirlenebilir.

Bu tür çalıșmalardan sağlıklı veri üretilebilmesi için 2 temel bilginin desağlıklı olması gerekmektedir. Bunlardan biri bitki su tüketimleridir. Bu konuda kapsamlı bir çalıșma yapılarak onar günlük dönemler için ülkemizde 29 iklim bölgesi ve 259 iklim istasyonunda 81 bitkinin su tüketimleri Penman-Monteith yöntemiyle hesaplanmıș ve kullanıcıların hizmetine sunulmuștur.

Diğer önemli veri ise bitkilerin üretim girdi ve maliyetleri ile net gelir değerleridir. Bu bilgiler il-ilçe bazında Gıda Tarım ve Hayvancılık Bakanlığı tarafından hazırlanmakta ve Tarım Reformu Genel Müdürlüğü tarafından kontrol edilerek kullanıcılara verilmektedir. Bu verilerin kontrollerinin yapılarak kullanıcılara verilmesinde zaman zaman yașanan aksaklıkların giderilmesinde yarar vardır.

Çalıșmada elde edilen sonuçların sulama politikaları ve sulama etkinliği konusunda çalıșan ilgili kamu-kurum ve özel sektör uzmanlarına yararlı olması beklenmektedir. 
Havza bazlı modelleme sonuclarının:

- Komșu-yakın havzalar arasında su nakline karar verilmesinde (iki havzadan elde edilecek toplam gelirin maksimize edilebilmesi için, sosyal adalet te göz önüne alınarak suyun optimum paylașımında),

- Havzalar bazında sulama yatırımlarına karar verilmesinde,

- Havza bazlı desteklemelere karar verilmesinde,

- Havza bazlı sektörel su tahsisi ile ilgili projelerde yararlı olması beklenmektedir.

Bu çalıșmalar yağıș açısından ortalama koșullar için yapılabildiği gibi, hafif, orta ve șiddetli kurak koșullar için de yapılabilmektedir, elde edilen sonuçlar gelecekte farklı șiddetteki kurak yıllarda kıt su kaynaklarının yönetiminde kullanılabilecektir.

\section{KAYNAKLAR}

Anonim (2016). Seyhan Havzası sektörel su tahsis planı. Su Yönetimi Genel Müdürlüğü, Ankara.

Anonim (2017). Türkiye'de sulanan bitkilerin bitki su tüketimleri. Tarımsal Araștırmalar ve Politikalar Genel Müdürlüğü, Ankara.

Güngör Y, Erözel AZ, Yıldırım O (2004). Sulama. Ankara Üniversitesi Ziraat Fakültesi Yayın No: 1540, Ders Kitabı, p. 493, Ankara.

Kodal S (2011). Sulama programlaması ve optimum bitki deseni tayini. Uluslararası Tarımsal Eğitim Merkezi Müdürlüğü (Basılmamıș Ders Notu), Ankara

Kodal S, Yıldırım YE, Yıldız D, Bingöl Ü, Aksu S, Karaca Bilgen $G$ (2016). Tarımsal sulama politikaları sulama yönetimi ve sulama etkinliğinin değerlendirilmesi. Gıda Tarım ve Hayvancılık Bakanlığı Tarımsal Araștırmalar ve Politikalar Genel Müdürlüğü, Araștırma - Geliștirme Destekleri Proje Sonuç Raporu, Ankara. 